\title{
Hyperferritinemia: the link between COVID-19, inflammation, and patient comorbidities
}

\author{
Angela Madalina Lazar ${ }^{1^{*}}$
}

\begin{abstract}
Ferritin is a key molecule in iron metabolism, as it stores the iron in a non-toxic form for the cells. Serum ferritin is a parameter that reflects the iron content of the body. However, serum ferritin is also an acute-phase reactant protein, as increased levels of serum ferritin are reported in many diseases associated with inflammation. Hyperferritinemia was also reported in COVID-19 (the coronavirus disease 19) patients, where it is considered an independent prognostic factor for the patients, indicating increased severity of the disease, risk for complications, and death. Certain categories of patients (older, those with comorbidities) have an increased risk of SARS-CoV-2 (severe acute respiratory syndrome coronavirus 2) infectivity and developing more severe forms of COVID-19. Chronic/acute systemic inflammatory states often characterize such preexisting comorbidities. In the current paper, a new pathogenic link is proposed and analyzed: between preexisting hyperferritinemia in the context of patient comorbidities (metabolic, cardiovascular, kidney, inflammatory, autoimmune, cancer) and the risk of SARS-CoV-2 infectivity and of developing more severe forms of infection. Ferritin per se can be a causal agent in COVID-19, as it can generate and aggravate inflammation and contributes to the development of a severe cytokine storm. A severe, uncontrolled inflammatory state occurs, triggered by the high levels of serum ferritin, preexisting comorbidities, and SARS-CoV-2 infection, cause of lethality in many patients. The inflammatory stimuli can further aggravate the infection by activating ADAM-17 (disintegrin and metalloprotease 17), a key enzyme involved in ACE2 (angiotensin-converting enzyme 2) activation and viral infectivity. In this context, iron chelators and antioxidants could become potential lines of treatment in COVID19.

Keywords: Hyperferritinemia, Serum Ferritin, SARS-CoV-2; COVID-19, Metabolic, Cardiovascular; Inflammatory; Diseases, Cancer; Cytokine Storm, Romania
\end{abstract}

\section{Background}

Ferritin functions and structural features

Ferritin is a highly conserved molecule, present from prokaryotes to vertebrate organisms, first described in 1937 by Victor Laufberger and extracted from horse spleen [1-4]. It is a nanocage protein that is a key player in iron metabolism, as it stores iron in a non-toxic form for the cell $[5,6]$. It is also essential for iron recycling depending on cellular needs. Iron is required for a vast array of processes and reactions, being able to act as a donor/receiver of electrons and intervening in various processes either as a cofactor or a catalyst: cell energy production, mitochondrial respiration, RNA and DNA synthesis, protein synthesis; it is essential for the production of the heme groups of hemoglobin and therefore for oxygen

*Correspondence: angelalazar.2008@yahoo.com

${ }^{1}$ Department of Functional Sciences, University of Medicine and Pharmacy

"Carol Davila" Bucharest, Romania.

Full list of author information is available at the end of the article transport and cellular oxygenation; synthesis of other molecules similar to hemoglobin, such as myoglobin, cytochromes; irondependent histone demethylases; various enzymes; formation of iron-sulfur clusters; cell survival and proliferation; prevention of oxidative damage (antioxidant role of ferritin) or, on the contrary, generation of free oxygen reactive species (free iron); immuno-modulatory functions [6-9]. Free iron is very toxic as it can accept or donate electrons to other molecules, leading to cellular damage; it also reacts with free oxygen radicals (Fenton and Haber-Weiss reactions) and leads to even more aggressive reactive oxygen species [8-11]. Therefore, iron metabolism, circulation, oxidation states, and storage must be very tightly regulated processes, impeding free iron toxicity and iron overload but allowing for an adequate release of iron for the cellular needs [12]. The classical, ubiquitously present ferritin comprises 24 subunits that self-assemble into an almost spherical cage with an external and internal diameter of $12 \mathrm{~nm}$ and $8 \mathrm{~nm}$, respectively [1,7]. Invertebrates, two types of ferritin 
subunits assemble to form the ferritin molecule: L (light) and $\mathrm{H}$ (heavy) ferritins, genetically encoded on the $11 \mathrm{q}$ and $19 \mathrm{q}$ chromosomes in humans. The ratio of $\mathrm{H} / \mathrm{L}-$ ferritin subunits is variable depending on the tissue, type of cell, cell subcompartment, metabolic rate, environmental factors, growth factors, translational and post-translational changes, and the presence of a large array of diseases $[3,4,6,8,10,13,14]$. The $\mathrm{H}$-subunit has ferroxidase activity and plays the key role of oxidizing ferrous ions $(\mathrm{Fe} 2+)$ to ferric ions $(\mathrm{Fe} 3+)$ that can be further be stored in a mineralized, stable internal core of ferritin $[6,13]$. Out of the multiple oxidation iron states (from -2 to +6 ), $\mathrm{Fe} 3+$ is the most stable, non-toxic iron state $[7,15]$. The process of iron oxidation from $\mathrm{Fe} 2+$ to $\mathrm{Fe} 3+$ is therefore essential for the conversion of iron to a non-toxic form that can be stored inside of the cell; it is also important as it consumes free oxygen radicals in the process of iron oxidation that would otherwise accumulate and lead to cell damage [3, 8]. L-ferritin subunit lacks a ferroxidase activity; it has a salt bridge in its folds and therefore plays a role only in the stability of the ferritin cage and in the ferric iron storage $[1,13]$. As the two subtypes of ferritin units have functional and structural differences, the ratio between the two in the ferritin nanocage differs between tissues, depending on the metabolic rate and need for a fast release of iron for incorporation into proteins. For example, in tissues characterized by high metabolic rates and the generation of a considerable amount of reactive oxygen species, such as the brain, heart, kidney, there is a predominant expression of the $\mathrm{H}$ ferritin in the ferritin nanocage. Instead, in tissues characterized by important iron storage, such as the liver and spleen, there is more L-ferritin than $\mathrm{H}$-ferritin into the cells $[3,6,9]$.

\section{Types of ferritin}

There are three types of intracellular ferritin in humans: cytosolic, nuclear, and mitochondrial [9]. Nuclear ferritin forms $\mathrm{H}$-subunits, while both $\mathrm{L}$ - and $\mathrm{H}$-ferritins are present in the cytosol [6]. Mitochondrial ferritin is very similar to the $\mathrm{H}$ subunit ferritin, with a $79 \%$ homology between the two; it is expressed mainly in the tissues characterized by high metabolic rates, having a protective role against the oxidative stress, and being uncorrelated to the cellular iron content $[1,3]$. Cellular ferritin synthesis is stimulated by high iron levels, oxidative stress, inflammatory stimuli/pathways. As $\mathrm{H}$ - and L- ferritin promoters have an antioxidant responsive element, ferritin synthesis is influenced by oxidative stress. Also, there is a hypoxia-responsive element in the 5'-promoter region of the ferritins, explaining why cellular ferritin levels increase during hypoxia [3].

\section{Serum ferritin}

Ferritin is also found in the serum and various liquids, such as cerebrospinal fluid, synovial fluid, and urine, being constituted only from L-subunits $[3,9]$. Serum L-ferritin is one of the tiniest understood molecules, although it is a laboratory test more and more requested in clinical practice [10]. It is not known if it is a monomeric or multimeric structure, and its functions are of unclear significance yet. Although insufficiently ascertained, circulating L-ferritin would act as an iron deliverer for cells [9]. Despite the limitations regarding its knowledge, serum ferritin is considered a very valuable clinical parameter. It can provide information regarding the body's iron content and differentiate between iron-deficiency anemia and other causes of anemia $[5,6,9,10]$. However, serum ferritin levels do not always correlate well with the iron organism levels, as they can be influenced by many factors and diseases $[6,9,10,16,17]$. Also, serum ferritin stores only a small amount of iron [4], and therefore its quantification offers only limited information in this regard. The sources of serum ferritin are non-classical pathways secretion out of the cells into the serum; and release into the serum as a result of cell damage and death $[1,9,10,18,19]$. Various stimuli, such as proinflammatory cytokines (interleukin 1 (IL-1), interleukin 6 (IL6), interleukin 10 (IL-10), tumor necrosis factor-alpha (TNFalpha), and interferon-gamma (IFN-gamma) that act via NF-kB pathway), growth factor or hypoxia can lead to increased secretion of ferritin $[9,10]$. One of the significant sources of ferritin is the macrophages, which secrete it along with other cytokines [6, 19]; another important source can be the hepatocytes $[9,10]$. After macrophage release, serum ferritin is physiologically glycosylated to a necessary extent $(50-80 \%$ of the serum ferritin); a lower or a higher level of glycosylation has been associated with various diseases $[6,10]$. The normal serum ferritin range is up to $200 \mu \mathrm{g} / \mathrm{L}$ in females and up to 300 $\mu \mathrm{g} / \mathrm{L}$ in males $[5,10]$. The serum ferritin appears to correlate well with the levels of intracellular ferritin, and high intracellular ferritin will be usually paralleled by hyperferritinemia. Hyperferritinemia can indicate a high level of iron or, maybe even more frequently, the presence of one/multiple diseases characterized by inflammatory states. A high level of iron is toxic [17] and determines an increase in ferritin generation via the iron regulatory proteins 1 and 2 (IRP 1 and 2) acting on IRE (iron response elements) present at the 5'UTR of the ferritin transcripts $[1,2,10]$. It was reported that inflammatory stimuli mainly induce an increase in $\mathrm{H}$-ferritin level, while high iron levels of L-ferritin [9].

Increased serum ferritin levels in diseases

Serum ferritin and intracellular ferritin have markedly increased levels in many inflammatory autoimmune diseases and acute phase reactions $[10,19,20]$. Such diseases that are characterized by chronic or acute inflammation, altered iron metabolism, and associate high serum ferritin levels include infections (acute, chronic, sepsis; viral, such as influenza infection, HCV and HIV; bacterial (including tuberculosis); autoimmune diseases, such as rheumatoid arthritis, systemic erythematosus lupus; kidney diseases; cancer (breast, colorectal, non-small lung cancer, prostate, pancreatic, oral, ovarian, renal); metabolic diseases (diabetes mellitus, obesity, dyslipidemia); cardiovascular diseases including hypertension; neurodegenerative diseases, such as Parkinson, Alzheimer, multiple sclerosis $[1,2,4,10,13,16,21-35]$. The inflammatory state/chronic inflammatory microenvironment is considered a consequence, a trigger, and/or an aggravating factor for the diseases mentioned above, leading to increased patient morbidity and mortality rates and the development of other severe chronic diseases [30 36-39]. Older age and male patients usually have higher serum ferritin levels than younger and female counterparts [40-45]. An elevated serum ferritin level in such diseases is considered an inflammatory marker, an acute phase reactant. It can be used along with other markers (Creactive protein, procalcitonin, lactate dehydrogenase (LDH), fibrinogen, D-dimers, erythrocyte sedimentation rate (ESR), IL6 , etc.) for a better interpretation of disease evolution. The significantly increased levels of serum ferritin seen in the mentioned diseases and states correlate very well with the severity degree of the disease. Therefore, serum ferritin levels can be used as prognostic markers for the disease evolution, risk of developing severe complications, and death $[19,20]$. It was reported that a ferritin level higher than $200 \mu \mathrm{g} / \mathrm{L}$ is a clear indicator for an increased risk of mortality for the patients with the previously mentioned diseases, the most critical cumulative 
risk being at ferritin levels higher than $600 \mu \mathrm{g} / \mathrm{L}$ [10]. Also, elevated serum ferritin levels can predict the development of such diseases that develop under chronic systemic proinflammatory states [46-48]. Even a link between inflammation- metabolic syndrome- high serum ferritin levels and the risk of developing other diseases, such as cardiovascular, was reported [49, 50]. That is, ferritin level holds a prognostic significance. However, it is not known whether the high levels of serum ferritin seen in the multiple diseases mentioned above are a cause or a secondary consequence, nor if they can exhibit protecting or, on the contrary, aggravating effects in the course of a pathological process. It is not known whether there is an etiologic role for ferritin in the mentioned diseases $[6,10,51]$. Some studies report a pro-inflammatory effect of ferritin per se $[10,14,16$, 51], while others consider that ferritin can act as a protective factor in specific pathologies (e.g., protective effects of $\mathrm{H}$ ferritin against acute kidney injury or vascular calcification) [1]. The increase in the ferritin levels seen in the inflammatory states can initially represent a mechanism of protection against a dangerous external agent (virus, bacteria, fungi) or internal (abnormal, compromised, toxic structures, such as in autoimmune diseases, neurodegenerative diseases, metabolic diseases, cancer). Pathogens and cancer cells require high iron levels for their survival and multiplication; in the case of cancers, iron is also essential for epithelial to mesenchymal transition, migration, and metastasis [6]. In the scenario of infections, ferritin might be a protective molecule as it sequestrates into intracellular stores, preventing the iron from being used by the pathogenic agents [9]; also, it has an antioxidant role. At the same time, serum ferritin could display immune-modulatory or even immunosuppressive roles, limiting the detrimental uncontrolled inflammatory storm [2, 9, 51]. By its anti-apoptotic functions, ferritin might determine a chronic tolerance to infections like hepatitis $\mathrm{C}$ virus, malaria, mycobacteria, HIV, and even sepsis [1,9]. In infections and ferritin, another player intervenes as well: hepcidin. Hepcidin, a relatively newly described molecule produced in the liver, physiologically prevents iron release from the cells via ferroportin; hepcidin also inhibits iron absorption by the enterocytes. Therefore, hepcidin also limits pathogens' iron access $[4,8,10,11]$. However, the opposite, detrimental effect of deregulated hyperferritinemia is even more frequently reported as a pathogenic vicious circle of disease can occur. Ferritin can determine more inflammation, aggravating the infection [14]. More ferritin can release more free iron from the cells; high free iron signals for even more ferritin synthesis, oxidative stress, inflammation, and cellular damage; excess ferritin can lead to the generation of ferritin aggregates, as described in some genetic ferritin disorders [3]. Such a deregulated process has also been described in neurodegenerative diseases (Alzheimer, Parkinson), although it is unclear whether ferritin metabolism alteration is the etiologic agent or only a consequence of the disease. However, in infections, hepcidin production is increased, leading to pronounced sequestration of iron into the cells, especially into macrophages, aiming to deprive the pathogens of it $[8,12]$. This explains a chronic inflammatory type of anemia in such chronic diseases $[4,8]$. At the same time, important iron sequestration into the host cells (via increased intracellular ferritin and following hepcidin production) would potentially become toxic; the ferritin iron storage capacity is probably saturable, and upon iron saturation, ferritinophagy and ferritinoptosis will ensue; there will be freer iron into the cells, oxidative damage, and cell death.
In cancer, more ferritin and intracellular iron stores have also been described. Iron is helpful for the cancer cells as it is a catalyst for the histone demethylation, a process required for epigenetic plasticity; also, more intracellular ferritin protects the cell from oxidative damage; otherwise, such significant oxidative stress could easily affect the cells characterized by high metabolic rates, as cancer cells [1, 6, 9]. Ferritin might be pro-oncogenic by promoting oxidative stress, followed by lipid peroxidation, DNA strand damage, mutagenesis [4,10]. However, elevated ferritin levels can activate pro-inflammatory macrophages associated with cancer cells that appear to function for cancer progression $[6,9]$.

Ferritin- a link between various comorbidities and COVID19

A recent observation is that in COVID-19 infection, there are increased levels of serum ferritin (hyperferritinemia, that is more than $300 \mu \mathrm{g}$ ferritin/L), along with other pro-inflammatory markers (IL-1, IL-6, TNF-alpha, IFN-gamma, D-dimers, LDH, procalcitonin, C-reactive protein). In fact, a 3 to 4 times higher serum ferritin level was reported in the COVID-19 nonsurvivors $[2,6,16,19,51]$. Also, higher serum ferritin levels were reported in patients with thrombotic complications than in the others [16]. Hyperferritinemia correlates well with the severity of the COVID-19, and the serum ferritin levels increase during the aggravation of the infection $[19,52]$. Therefore, high serum ferritin levels indicate a very severe infection and poor prognosis, predicting the development of life-threatening complications, such as respiratory failure, organ dysfunction, need for ICU hospitalization, and death $[11,14,16,19,20]$. Interestingly, serum ferritin levels begin to decrease when the COVID-19 patients' state begins to ameliorate [51]. Actually, ferritin levels are considered an independent prognostic factor for COVID-19 patients [19]. Also, ferritin levels have been proposed as a marker of viral replication [16]. It is already ascertained that specific categories of patients have a higher risk of SARS-CoV-2 infectivity and developing more aggressive, severe forms of COVID-19. Such categories are older, male patients; also patients with preexisting comorbidities such as hypertension, cardiovascular diseases; metabolic diseases (diabetes mellitus, obesity, dyslipidemia, and steatosis); kidney diseases; cancer; inflammatory and autoimmune diseases $[1,16$, 19, 29, 53-58]. Until now, no apparent, final, and unanimous explanation was found regarding the mechanisms behind such vulnerability for the SARS-CoV-2 severe infections in the categories mentioned above of patients. As ACE2 are the receptors for the SARS-CoV-2 [59], a temporary hypothesis was a higher expression of ACE2 receptors in such diseases, male patients, and older age, increasing the risk and severity of SARS-CoV-2 infection [53, 60-65]. However, this hypothesis was not validated afterward. For example, children have higher levels of whole-membrane ACE2 receptors, but instead, they have a low risk of infectivity or of developing symptomatic or severe forms of COVID-19. Usually, if they are infected, they develop asymptomatic/oligosymptomatic mild forms of infection, and only children with preexisting severe comorbidities can present more severe forms of the disease [66]. The explanation, therefore, could come not from a higher expression of ACE2 receptors but their hyperferritinemia status, cause and/or consequence, as well as a contributor to their chronic inflammatory states. There is already a report where the authors consider a link between inflammation, cancer, and more severe forms of SARS-CoV-2 infection [29].

In this context, we hypothesize a causal link between preexisting elevated serum ferritin levels due to various patient 
comorbidities (that associate an inflammatory state and oxidative stress) and a higher risk of SARS-CoV-2 infectivity of developing more severe forms of infection. The chronic/acute inflammation reported in such diseases sustained by hyperferritinemia creates a vulnerable status for other infections, including SARS-CoV-2 infection. Such a vulnerability fueled by the preexisting immune dysregulation and severe pro-inflammatory status [16] can more rapidly trigger a veritable cytokine storm. It is ascertained that the inflammatory states, via cytokines and chemokines, determine an upregulation of ferritin expression with the accumulation of more and more ferritin into the cells [14]. Pro-inflammatory cytokines such as IL-1, IL-6, IL-10, TNF-alpha, and IFNgamma, massively produced in COVID-19 as well, will therefore increase ferritin levels $[1,10,20,51]$. It appears that once produced in excess; ferritin will feed a positive feedback loop, determining more inflammation, the generation of more pro-inflammatory cytokines, and the activation of M1 macrophages [51]. Ferritin (H-ferritin) was reported to activate M1 macrophages, production of cytokines, leading to inflammation and even pyroptotic cell death [14,16]; it regulates many intracellular signaling pathways, such as proinflammatory pathways, with the activation of the NF-kB (nuclear factor kappa-B) that leads to more inflammation; it also regulates c-Jun $\mathrm{N}$-terminal kinase (JNK) pathway (ferritin inhibits it, preventing cell apoptosis and promoting survival); ERK pathway, MAPK-pathway, and others [3, 4, 6, 9]. It has also been reported that ferritin can directly, at the nuclear level, stimulate the gene expression of several pro-inflammatory cytokines, such as IL-1 beta, IL-6, TNF-alpha, and others [9, 19]. The excessively produced inflammatory mediators will stimulate ferritinophagy, with increased intracellular free iron, leading to oxidative stress, lipid peroxidation, and ferroptosis $[2,6]$. Ferroptosis is an iron-regulated form of cell death [3]. Ferroptosis will promote inflammation, oxidative stress, and cell damage [9, 11]. COVID-19 itself is also a disease that is characterized by an exaggerated uncontrolled systemic inflammation and cytokine storm, similar to the macrophage activation syndrome, leading to organ dysfunction and damage, increased infection severity, and mortality $[2,11,16,19,20,58$, 67-70]. Therefore, a positive feedback loop of inflammation triggered by preexisting high ferritin levels [14] (in the context of diseases associated with chronic inflammatory states) could be detrimental for sure. Systemic inflammation with uncontrolled cytokine storm is recognized as a cause of mortality in COVID-19 patients $[6,14,51]$. In infections like COVID-19, cell damage by the viruses is another source of ferritin release into the serum, as reported in liver diseases. As ferritin assembly is dependent on environmental factors, including $\mathrm{pH}$, ferritin molecules will be able to disassemble into the serum, releasing toxic free iron that will determine oxidative stress, more inflammation, cytokine storm, and cellular damage, leading to multiple organ dysfunction and even death $[10,11]$. The SARS-CoV-2 virus also attacks hemoglobin, releasing toxic free iron, leading to oxidative stress and inflammation. The inflammatory state will determine more ferritin being produced [4]; in fact, a vicious, positive feedback loop is described between cytokines and ferritin [19]. The released free iron, the result of the hemoglobin attack by the virus, will also stimulate ferritin production; the result will be more inflammation and a pro-thrombotic state (free iron determines fibrinogen conversion to fibrin) [11]. SARS-CoV-2 can also mimic hepcidin, leading to increased ferritin levels and further inflammation [11].
Therefore, as ferritin per se can also lead to/aggravate inflammation $[9,14]$, it could be a key player in COVID-19 pathogenesis. The cytokine storm and ferritin lead to acute respiratory distress syndrome (ARDS) [16]. In this context, there are reports after postmortem analysis that SARS-CoV-2 does not determine pneumonia or ARDS per se; instead, free iron leads to oxidative damage, inflammation, and cellular and organ damage [11]. That could be the explanation why in COVID-19 patients, extremely high levels of serum ferritins (that signal or even trigger inflammation) were observed in severe forms of infection, along with the occurrence of complications and correlated with a poor prognostic and survival. Additional mechanisms to explain why a preexisting inflammatory status (as reported in patients with essential comorbidities) has an increased risk of SARS-CoV-2 infection could intervene. Inflammatory stimuli and reactive oxygen species (the result of increased levels of iron released from cells) lead to an activation of key enzymes for viral infectivities, such as ADAM-17 or even of ACE2, that could intervene as an activating enzyme for the SARS-CoV-2 as well, as hypothesized in a recent study [71-74]. ADAM-17, also known as TACE, is known to activate membrane ACE2, a process important for viral infectivity; also, it can act as an activator enzyme for the SARS-CoV-2 as well, with putative cleavage of the spike protein required for viral fusion to the host cells [7174].

\section{Future perspectives}

In this context, considering that ferritin is one of the least understood molecules in disease, more research would be needed: to establish whether ferritin can act as a triggering factor for infections and other diseases or whether its increased levels are only a consequence. In this concern, international, large-scale multicentric research should be performed to link the serum ferritin and iron levels in various diseases and the risk of SARS-CoV-2 infectivity/risk of developing more severe forms of infection. However, such research is hindered by the difficulties in iron quantification in the serum and at intercellular levels. Also, more in vitro studies should be performed; macrophages and other cells, in various environmental conditions, should be exposed to different ferritin levels/ different types of ferritins, and the levels and types of released cytokines are measured afterward. In COVID19, a new question should be raised supplementary: whether ferritin does not indirectly/directly affect the expression and functionality of the membrane ACE2 receptors. This question appears of significance as in severe COVID-19 patients, hyperferritinemia (along with other serum pro-inflammatory markers) can be seen but paralleled by an increase in the serum enzymatic activity of ACE2 [52]. Understanding the hyperferritinemia significance in COVID-19 patients with significant comorbidities gains considerable significance. Such an understanding would be useful in designing prevention strategies for the patients' categories at increased risk of severe forms of disease and in treating such patients more efficiently. At the same time, the design and implementation of specific preventive strategies for the patients at risk are essential, as it was shown that we could not control pandemics only through measures of isolation and quarantine, especially when dealing with a virus that can reappear in successive waves across the globe, due to its impressive registry of mutations [75-78]. Suppose we accept the ferritin causal roles in infections like COVID-19. In that case, we could intervene with iron chelators (deferoxamine, deferasirox, deferiprone, or the natural lactoferrin) and antioxidants at the initial stages/in the course of 
the infection to limit the progress and the severity of the disease. Some authors already propose an attitude to fight cancer progression and severe infections, such as AIDS and COVID-19 [9-11]. In COVID-19, iron chelators could even prevent the SARS-CoV-2 from binding to its cellular receptors, as described by some authors [11]. One explanation for this effect could be that the iron chelators bind the virus; the other is that the chelators bind the viral membrane receptors. Also, lactoferrin binds to heparan sulfate proteoglycans that appear essential for SARS-CoV-2 binding to the ACE2 receptors. It appears that lactoferrin could also repress intracellular viral replication (11). We could also exploit the bio-ferritin nanocages to deliver enhanced therapies for COVID-19 patients, as envisioned already for cancer therapy [6]. Such an example would be Artemisia-derived drugs, used to treat malaria and considered in treating SARS-CoV-2 infected patients. Artesunate can increase the lysosomal degradation of intracellular ferritin with the release of free iron and oxidative stress, leading to the death of the infected cells (therapeutic induction of ferroptosis) $[6,79,80]$. Therefore, there is a clear need for more research to enable knowledge on the exact link between preexisting patient comorbidities, serum ferritin levels, and COVID-19. Such a discovery would make possible a better prediction and prevention of SARS-CoV-2 infectivity, based on a clinically generally available determination of serum ferritin levels. A single aspect regarding ferritin and disease can be ascertained for now: nothing is for sure yet. Until better knowledge is achieved, valuable information, however, emerges: the usefulness of ferritin levels in predicting the course of COVID-19 and other diseases.

\section{Abbreviation}

SARS-Cov-2: Severe Acute Respiratory Syndrome Coronavirus 2; COVID-19: The Coronavirus Disease 19; ACE2: Angiotensin-Converting Enzyme 2; ADAM 17: Disintegrin And Metalloprotease 17 (ADAM-17), Also Known As TACE (Tumor Necrosis Factor-A-Converting Enzyme); RNA: Ribonucleic Acid; DNA: Deoxyribonucleic Acid; L-Ferritin: Light Ferritin; H-Ferritin: Heavy Ferritin; Fe2+: Ferrous Ions; Fe3+: Ferric Ions; IL: Interleukin; IL-1: Interleukin 1; IL-6: Interleukin 6; IL-10: Interleukin 10; TNF-Alpha: TumorNecrosis Factor Alpha; IFN-Gamma: Interferon Gamma; NF$\mathrm{Kb}$ : Nuclear Factor Kappa-B; IRP 1 And 2: Iron Regulatory Proteins 1 And 2; IRE: Iron Response Elements; HCV: Hepatitis C Virus; HIV: Human Immunodeficiency Virus; LDH: Lactate Dehydrogenase; ESR: Erythrocyte Sedimentation Rate; ICU: Intensive Care Unit; JNK: C-Jun N-Terminal Kinase Pathway; ERK: Extracellular Signal-Regulated Kinase Pathway; MAPK Pathway: Mitogen-Activated Protein Kinase Pathway; ARDS: Acute Respiratory Distress Syndrome; AIDS: Acquired Immunodeficiency Syndrome..

\section{Declaration}

Acknowledgment

None.

\section{Funding}

The author received no financial support for the research, authorship, and/or publication of this article.

Availability of data and materials

Data will be available by emailing angelalazar.2008@yahoo.com

\section{Authors' contributions}

Angela Madalina Lazar (AML) is the principal investigator of this manuscript (Viewpoint). AML is the responsible author for the study concept, design, writing, reviewing, editing, and approving the manuscript in its final form. AML has read and approved the final manuscript.

Ethics approval and consent to participate

We conducted the research following the Declaration of Helsinki. However, Viewpoint Articles need no ethics committee approval.

\section{Consent for publication}

Not applicable

Competing interest

The authors declare that they have no competing interest

\section{Open Access}

This article is distributed under the terms of the Creative Commons Attribution 4.0 International License (http://creativecommons.org/licenses/by/4.0/), which permits unrestricted use, distribution, and reproduction in any medium, provided you give appropriate credit to the original author(s) and the source, provide a link to the Creative Commons license, and indicate if changes were made. The Creative Commons Public Domain Dedication

waiver (http://creativecommons.org/publicdomain/zero/1.0/) applies to the data made available in this article, unless otherwise stated.

Author details

${ }^{1}$ Department of Functional Sciences, University of Medicine and Pharmacy "Carol Davila" Bucharest, Romania.

Article Info

Received: 03 December 2021

Accepted: 23 December 2020

Published: 31 December 202

\section{References}

1. McCullough K, Bolisetty S. Ferritins in kidney disease. Semin Nephrol 2020;

40(2):160-172 doi:10.1016/j.semnephrol.2020.01.007.

2. Alam JM, Ali H. Significance of Ferritin as Biomarker in SARS Corona virus (Covid-19) infection and complications: A Review. Chemistry Research Journal 2020; 5(6): 59-64.

3. Zhang J, Chen X, Hong J, Tang A, Liu Y, Xie N, Nie G, Yan X, Liang M. Biochemistry of mammalian ferritins in the regulation of cellular iron homeostasis and oxidative responses. Science China Life Sciences 2020; 64(3):352-362 (2021); https://doi.org/10.1007/s11427-020-1795-4.

4. Wang W, Knovich MA, Coffman LG, Torti FM, Torti SV. Serum Ferritin: Past, Present, Future. Biochim Biophys Acta 2010; 1800(8): 760-769. doi:10.1016/j.bbagen.2010.03.011.

5. Anderson GJ, Bardou-Jacquet E. Revisiting hemochromatosis : genetic vs. phenotypic manifestations. ANn Transl Med 2021; 9(8): 731. http://dx.doi.org/10.21037/atm-20-5512.

6. Plays M, Müller S, Rodriguez R. Chemistry and biology of ferritin. Metallomics. 2021;13(5):mfab021 doi:10.1093/mtomcs/mfab021

7. Bradley JM, Pullin J, Moore GR, Svistunenko DA, Hemmings $\mathrm{AM}$, le Brun NE. Routes of iron entry into, and exit from, the catalytic ferroxidase sites of the prokaryotic ferritin SynFtn. Dalton Trans 2020; 49:1545-1554. DOI:10.1039/c9dt03570b.

8. Azeez M. The role of Ferritin in Iron Homeostasis. IDOSR Journal of Biology, Chemistry and Pharmacy 2020; 5(1):5-11.

9. Moreira AC, Mesquita G, Gomes MS. Ferritin: An Inflammatory Player Keeping Iron at the Core of Pathogen-Host Interactions. 
Microorganisms 2020

$8: 589$. doi:10.3390/microorganisms8040589.

10. Sandnes M, Ulvik RJ, Vorland M, Reikvam H. HyperferritinemiaA Clinical Overview. Journal of Clinical Medicine 2021; 10:2008. https://doi.org/10.3390/jcm10092008.

11. Habib HM, Ibrahim S, Zaim A, Ibrahim WH. The role of iron in the pathogenesis of COVID-19 and possible treatment with lactoferrin and other iron chelators. Biomedicine \&Pharmacotherapy 2021; 136:111228.https://doi.org/10.1016/j.biopha.2021.111228.

12. Kowdley KV, Gochanour EM, Sundaram V, Shah RA, Handa P. Hepcidin Signaling in Health and Disease: Ironing Out the Details. Hepatology Communications 2021; 5(5):723-735.

13. Irimia-Dominguez J, Sun C, Li K, Muhoberac BB, Hallinan GI, Garringer HJ, Ghetti B, Jiang W, Vidal R. Cryo-EM structures and functional characterization of homo- and heteropolymers of human ferritin variants. Scientific Reports 2020; 10:20666.https://doi.org/10.1038/s41598-020-77717-4

14. Ruscitti P, Di Benedetto P, Berardicurti O, Panzera N, Grazia N, Lizzi AR, Cipriani P, Shoenfeld Y, Giacomelli R. Proinflammatory properties of $\mathrm{H}$-ferritin on human macrophages, ex vivo and in vitro observations. Scientific Reports 2020; 10:12232.

15. Noemia LM, Carmen VL . Ferritin: Could be a Health Indicator. J Fam Med Dis Prev 2018;4:078. doi.org/10.23937/2469. 5793/1510078.

16. Cheng L, Li H, Li L, Liu C, Yan S, Chen H, Li Y. Ferritin in the coronavirus disease 2019 (COVID-19): A systematic review and meta-analysis. J Clin Lab Anal 2020; 34: e23618. https://doi.org/10.1002/jcla.23618.

17. Piperno A, Pelucchi S, Mariani R. Inherited iron overload disorders. Trans Gastroenterol Hepatol 2020; 5:25. https://dx.doi.org/10.21037/tgh.2019.11.15.

18. Kell DB , Pretorius E . Serum ferritin is an important inflammatory disease marker, as it is mainly a leakage product from damaged cells. Metallomics 2014; 6: 748-773. DOI: 10.1039/C3MT00347G

19. Deng F, Zhang L, Lyu 1, Lu Z, Gao D, Ma X, Guo Y, Wang R, Gong S, Jiang W. Increased levels of ferritin on admission predicts intensive care unit mortality in patients with COVID-19. Med Clin (Barc) 2021; 509: 324331.https://doi.org/10.1016/j.cca.2020.06.033.

20. Ahmed S, Ahmed ZA, Siddiqui I, Rashid NH, Mansoor M, Jafri L. Annals of medicine and Surgery 2021; 63:102163. https://doi.org/10.1016/j.amsu.2021.02.009.

21. Kadoglou NPE, Biddulph JP, Rafnsson SB, Trivella M, Nihoyannopoulos P, Demakakos P. The association of ferritin with cardiovascular and all-cause mortality in communitydwellers: The English longitudinal study of ageing. PLOS ONE 2017; 12(6):e0178994.

22. Avila F, Echeverría G, Pérez D, Martinez C, Strobel P, Castillo O, Villaroel L, Mezzano D, Rozowski J, Urquiaga I, Leighton F. Serum Ferritin Is Associated with Metabolic Syndrome and Red Meat Consumption. Oxid Med Cell Longev. 2015;2015:769739. doi: 10.1155/2015/769739.

23. Andrade-Oliveira V, Foresto-Neto O, Watanabe IKM, Zatz R, Câmara NOS. Inflammation in Renal Diseases: New and Old Players. Front Pharmacol. 2019;10:1192. doi: 10.3389/fphar.2019.01192.

24. Fioranelli M, Bottaccioli AG, Bottaccioli F, Bianchi M, Rovesti M, Roccia MG. Stress and Inflammation in Coronary Artery
Disease: A Review Psychoneuroendocrineimmunology-Based. Front Immunol. 2018;9:2031. doi: 10.3389/fimmu.2018.02031.

25. Tbahriti HF, Meknassi D, Moussaoui R, Messaoudi A, Zemour L, Kaddous A, Bouchenak M, Mekki K. Inflammatory status in chronic renal failure: The role of homocysteinemia and proinflammatory cytokines. World J Nephrol. 2013;2(2):31-7. doi: 10.5527/wjn.v2.i2.31.

26. Lopez-Candales A, Hernández Burgos PM, Hernandez-Suarez DF, Harris D. Linking Chronic Inflammation with Cardiovascular Disease: From Normal Aging to the Metabolic Syndrome. J Nat Sci. 2017;3(4):e341.

27. Djuric Zora. Chapter 41- Reducing Proinflammatory States with the Mediterranean Diet: Possible mechanism for Cancer Prevention. Academic Press 2015; pages 451-459. https://doi.org/10.1016/B978-0-12-407849-9.00041-5

28. Sachinidis A, Doumas M, Imprialos K, Stavropoulos K, Katsimardou A, Athyros VG. Dysmetabolic Iron Overload in Metabolic Syndrome. Current Pharmaceutical Design 2020; 26(10); https://doi.org/10.2174/1381612826666200130090703.

29. Dettorre GM, Dolly S, Loizidou A On behalf of OnCovid study group, et al. Systemic pro-inflammatory response identifies patients with cancer with adverse outcomes from SARS-CoV-2 infection: the OnCovid Inflammatory Score. Journal for ImmunoTherapy of Cancer 2021;9:e002277. doi: 10.1136/jitc2020-002277

30. Qu X, Tang Y, Hua S. Immunological Approaches Towards Cancer and Inflammation: A Cross Talk. Front Immunol. 2018;9:563. doi: 10.3389/fimmu.2018.00563.

31. Di Lorenzo C, Dell'agli M, Colombo E, Sangiovanni E, Restani P. Metabolic syndrome and inflammation: a critical review of in vitro and clinical approaches for benefit assessment of plant food supplements. Evid Based Complement Alternat Med. 2013;2013:782461. doi: 10.1155/2013/782461.

32. Monserrat-Mesquida M, Quetglas-Llabrés M, Capó X, et al. Metabolic Syndrome is Associated with Oxidative Stress and Proinflammatory State. Antioxidants (Basel). 2020;9(3):236.doi:10.3390/antiox9030236.

33. Devaraj S, Dasu MR, Jialal I. Diabetes is a proinflammatory state: a translational perspective. Expert Rev Endocrinol Metab. 2010; 5(1):19-28. doi:10.1586/eem.09.44.

34. Guedes JM, Neto JBM, Andaki AC, Pereira PF, Dias de Oliveira M, Dias RS, de Paula SO, Natali AJ, de Paula Rogério A, Edmar Lacerda Mendes EL. Association of inflammation, dyslipidemia, obesity and physical activity status in children. Motriz, Rio Claro 2016; $\quad 22 \quad$ (2) $\quad 18-26 . h t t p s: / / d o i . o r g / 10.1590 / S 1980-$ 6574201600020003

35. Tzang BS, Chen VC, Hsieh CC, Wang WK, Weng YP, Ho HY, Hsu YT, Hsaio HP, Weng JC, Chen YL. Differential associations of proinflammatory and anti-inflammatory cytokines with depression severity from noncancer status to breast cancer course and subsequent chemotherapy. BMC Cancer. 2020;20(1):686. doi: 10.1186/s12885-020-07181-w.

36. Amin MN, Siddiqui SA, Ibrahim M, Hakim ML, Ahammed MS, Kabir A, Sultana F. Inflammatory cytokines in the pathogenesis of cardiovascular disease and cancer. SAGE Open Med. 2020; 8:2050312120965752. doi: 10.1177/2050312120965752.

37. Gonzalez LL, Garrie K, Turner MD. Type 2 diabetes - An autoinflammatory disease driven by metabolic stress. Biochim Biophys Acta Mol Basis Dis. 2018;1864(11):3805-3823. doi: 10.1016/j.bbadis.2018.08.034 
38. Coussens LM, Werb Z. Inflammation and cancer. Nature. 2002;420(6917):860-867. doi:10.1038/nature01322.

39. Grivennikov SI, Greten FR, Karin M. Immunity, inflammation, and cancer. Cell. 2010;140(6):883-899. doi:10.1016/j.cell.2010.01.025.

40. Oh HL, Lee JA, Kim DH, Lim JS. Reference values for serum ferritin and percentage of transferrin saturation in Korean children and adolescents. Blood Research 2018; 53(1): 18-24.

41. Rushton DH, Barth JH. What is the evidence for gender differences in ferritin and Haemoglobin? Critical Reviews in Oncology/Hematology 2010; 73:1-9.

42. Lee Y-T, Wang W-Y, Kuo C-H, Lee M-Y, Lu Y-C, Hsiao C-Y, Hsu Y-H, Hung P-H. Older Age and High Serum Ferritin Levels Associated With the Risk of Chronic Cytopenia in Hemodialysis Patients. Frontiers in Medicine 2020; 7:568350. DOI=10.3389/fmed.2020.568350.

43. Goldhaber G, Segal G, Dagan A. Hyperferritinemia in the elderly can differentiate the bad from the worst: A retrospective cohort analysis. Medicine (Baltimore). 2020;99(31):e21419. doi:10.1097/MD.0000000000021419.

44. Seong JM, Yoon YS, Lee KS, Bae NY, Gi MY, Yoon H. Gender difference in relationship between serum ferritin and 25hydroxyvitamin D in Korean adults. PLoS ONE 2017; 12(5): e0177722. https://doi.org/10.1371/journal.pone.0177722.

45. Casale G, Bonora C, Migliavacca A, Zurita IE, de Nicola P. Serum Ferritin and Aging. Age and Ageing 1981; 10(2): 119-122; https://doi.org/10.1093/aging/10.2.119.

46. Liu J-R, Liu Y, Yin F-Z, Liu B-W. Sarrum ferritin, an early marker of cardiovascular risk : a study in Chinese men of fisrtdegree relatives with family history of type 2 diabetes. BMC Cardiovascular Disorders 2019; 19:82.

47. Sackett K, Cunderlik M, Sahni N, Killeen AA, Olson AP. Extreme Hyperferritinemia: Causes and Impact on Diagnostic Reasoning. Am J Clin Pathol. 2016;145(5):646-50. doi: 10.1093/ajcp/aqw053.

48. Kim MK, Baek HK, Song K-H, Kang MI,Choi JH, Bae JC, Park CY, Lee WY, Oh KW. Increased Serum Ferritin Predicts the Development of Hypertension Among Middle-Aged Men. American Journal of Hypertension 2012; 25(4): 492-497.

49. Tofano RJ, Pescinni-Salzedas LM, Chagas EFB, Detregiachi CRP, Araujo AC, Bechara MD, Rubira CJ, Barbalho SM. Association of Metabolic Syndrome and Hyperferritinemia in Patients at Cardiovascular Risk. Diabetes, Metabolic Syndrome and Obesity: Targets and Therapy 2020; 13: 3239-3248.

50. Battineni G, Sagaro GG, Chintalapudi N, Amenta F, Tomassoni D, Tayebati SK. Impact of Obesity-Induced Inflammation on Cardiovascular Diseases (CVD). Int J Mol Sci. 2021;22(9):4798. doi: 10.3390/ijms22094798.

51. Gomez-Pastora J, Weigand M, Kim J, Wu X, Strayer J, Palmer AF, Zborowski M, Yazer M, Chalmers JJ. Hyperferritinemia in critically ill COVID-19 patients- Is ferritin the product of inflammation or a pathogenic mediator? Clinica Chimica Acta 2020; 249-251.

52. Nagy B, Fejes Z, Szentkereszty Z, Suto R, Varkonyi I, Ajzner E et al.. A dramatic rise in serum ACE2 in a critically ill COVID-19 patient. International Journal of Infectious Diseases 2021;103:412414.

53. Fang L, Karakiulakis G, Roth M. Are patients with hypertension and diabetes mellitus at increased risk for COVID-19 infection? Lancet Respir Med. 2020;8(4):e21. doi: 10.1016/S2213-
2600(20)30116-8. Erratum in: Lancet Respir Med. 2020 Jun;8(6):e54.

54. Tadic M, Cuspidi C. The influence of diabetes and hypertension on outcome in COVID-19 patients: Do we mix apples and oranges?. J Clin Hypertens 2021; 23: 235-237. https://doi.org/10.1111/jch.14145.

55. Apicella M, Campopiano MC, Mantuano M, Mazoni L, Coppelli A, Del Prato S. COVID-19 in people with diabetes: understanding the reasons for worse outcomes. Lancet Diabetes Endocrinol 2020: 8; 782-92; https://doi.org/10.1016/S2213-8587(20)30238-2.

56. Rastad, H., Ejtahed, HS., Mahdavi-Ghorabi, A., Arzaghi M, Safari A, Shahrestanaki E, et al. Factors associated with the poor outcomes in diabetic patients with COVID-19. J Diabetes Metab Disord 2020; 19: 1293-1302; https://doi.org/10.1007/s40200-02000646-6.

57. Parit R, Jajavel S. Association of ACE inhibitors and angiotensin type II blockers with ACE2 overexpression in COVID-19 comorbidities: A pathway-based analytical study. European Journal of Pharmacology 2021; 896: 173899. https://doi.org/10.1016/j.ejphar.2021.173899.

58. Lazar AM. Renin-angiotensin-aldosterone system inhibitors - a realm of confusion in COVID-19. Journal of Ideas in Health 2021; $4 \quad$ (Special2): 389-394. https://doi.org/10.47108/jidhealth.Vol4.IssSpecial2.125.

59. Lazar AM. Understanding SARS-CoV-2 features of infectivity, aggressiveness, and transmissibility: an insect-vector theory for SARS-CoV-2 dissemination. Journal of Ideas in Health 2021; 4(Special 1): 343-347; https://doi.org/10.47108/jidhealth.Vol4.IssSpecial1.109.

60. Pinto BGG, Oliveira AER, Singh Y, Jimenez L, Gonçalves ANA, Ogava RLT, Creighton R, Schatzmann Peron JP, Nakaya HI. ACE2 Expression Is Increased in the Lungs of Patients With Comorbidities Associated With Severe COVID-19. J Infect Dis. 2020;222(4):556-563. doi: 10.1093/infdis/jiaa332.

61. Jacobs M, Hannelore P. Van Eeckhoutte, Sara R. A. Wijnant, Wim Janssens, Guy F. Joos, Guy G. Brusselle, Ken R. Bracke.Increased expression of ACE2, the SARS-CoV-2 entry receptor, in alveolar and bronchial epithelium of smokers and COPD subjects. European Respiratory Journal 2020; 56: 2002378; DOI: 10.1183/13993003.02378-2020.

62. Kaseb AO, Mohamed YI, Malek AE, Raad II, Altameemi L, Li D, Kaseb OA, Kaseb SA, Selim A, Ma Q. TheImpact of Angiotensin-Converting Enzyme 2 (ACE2) Expression on the Incidence and Severity of COVID-19 Infection. Pathogens 2021; 10: 379.https://doi.org/10.3390/pathogens10030379.

63. Baker SA, Kwok S, Berry GJ, Montine TJ. Angiotensinconverting enzyme 2 (ACE2) expression increases with age in patients requiring mechanical ventilation. PLoS ONE 2021; 16(2):e0247060. https://doi.org/10.1371/journal.pone.0247060.

64. Iannelli A, Favre G, Frey S, Esnault V, Gugenheim J, Bouam S, Schiavo L, Tran A, Alifano M. Obesity and COVID-19: ACE 2, the Missing Tile. Obes Surg. 2020;30(11):4615-4617. doi:10.1007/s11695-020-04734-7.

65. Chen L, Li X, Chen M, Feng Y, Xiong C. The ACE2 expression in human heart indicates new potential mechanism of heart injury among patients infected with SARS-CoV-2 [published correction appears in Cardiovasc Res. 2020;116(12):1994]. Cardiovasc Res. 2020;116(6):1097-1100. doi:10.1093/cvr/cvaa078.

66. Zimmermann P, Curtis N. Arch Dis Child 2020;0:1-11. doi:10.1136/archdischild-2020-320338. 
67. Del Valle DM, Kim-Schulze S, Huang HH, Beckmann ND, Nirenberg S, Wang B, Lavin Y, Swartz TH, Madduri D, Stock A, Marron TU, Xie H, Patel M, Tuballes K, Van Oekelen O, Rahman A, Kovatch P, Aberg JA, Schadt E, Jagannath S, Mazumdar M, Charney AW, Firpo-Betancourt A, Mendu DR, Jhang J, Reich D, Sigel K, Cordon-Cardo C, Feldmann M, Parekh S, Merad M, Gnjatic S. An inflammatory cytokine signature predicts COVID19 severity and survival. Nat Med. 2020;26(10):1636-1643. doi: 10.1038/s41591-020-1051-9.

68. Costela-Ruiz VJ, Illescas-Montes R, Puerta-Puerta JM, Ruiz C, Melguizo-Rodríguez L. SARS-CoV-2 infection: The role of cytokines in COVID-19 disease. Cytokine Growth Factor Rev. 2020;54:62-75. doi: 10.1016/j.cytogfr.2020.06.001.

69. Yang, L., Xie, X., Tu, Z., Fu J, Xu D, Zhou Y. The signal pathways and treatment of cytokine storm in COVID-19. Sig Transduct Target Ther 2021;6: 255. https://doi.org/10.1038/s41392-021-00679-0.

70. Rowaiye $\mathrm{AB}$, Okpalefe OA, Onuh Adejoke O, Ogidigo JO, Hannah Oladipo O, Ogu AC, Oli AN, Olofinase S, Onyekwere O, Rabiu Abubakar A, Jahan D, Islam S, Dutta S, Haque M. Attenuating the Effects of Novel COVID-19 (SARS-CoV-2) Infection-Induced Cytokine Storm and the Implications. Journal of Inflammation Research. $2021 \quad ; 14: 1487-1510 . \quad$ DOI: 10.2147/jir.s301784.

71. Haga S, Yamamoto N, Nakai-Murakami C, Osawa Y, Tokunaga $\mathrm{K}$, Sata $\mathrm{T}$ et al. Modulation of TNF- $\alpha$-converting enzyme by the spike protein of SARS-CoV and ACE2 induces TNF- $\alpha$ production and facilitates viral entry. PNAS 2008; 105 (22): 7809-7814. DOI: 10.1073/pnas.0711241105.

72. Lazar AM. ACE2 enzymatic role in the SARs-CoV-2 activation: a perspective through the evolutionary promiscuy and substrate diversity of enzymes. Journal of Ideas in Health 2021; 4(4): 581 587. https://doi.org/10.47108/jidhealth.Vol4Iss4.169.
73. Heurich A, Hofmann-Winkler H, Gierer S, Liepold Th, Jahn O, Pöhlmann S. (2014). TMPRSS2 and ADAM17 Cleave ACE2 Differentially and Only Proteolysis by TMPRSS2 Augments Entry Driven by the Severe Acute Respiratory Syndrome Coronavirus Spike Protein. Journal of Virology 88 (2), 12931307.

74. Liu M, Wang T, Zhou Y, Zhao Y, Zhang Y, LI J. Potential role of ACE2 in coronavirus disease 2019 (COVID-19) prevention and management. Journal of Translational Internal Medicine 2020 ; 8(1): 9-19.

75. Ali Jadoo SA (2020). The second wave of COVID-19 is knocking at the doors: have we learned the lesson? Journal of Ideas in Health. 2020; 3 (Special 1):183-184; https://doi.org/10.47108/jidhealth.Vol3.IssSpecial1.72.

76. Alhusseiny A, Latif I, Ali Jadoo SA. Covid-19 in Iraq: an estimated cost to treat patients at a private clinic. Journal of Ideas in Health2021; 4(1): 304-306. https://doi.org/10.47108/jidhealth.Vol4.Iss1.82.

77. Ali Jadoo SA, Alhusseiny A, Yaseen S, Al-Samarrai M, AlRawi R, Al-Delaimy A, Abed M, Hassooni H. Knowledge, attitude, and practice toward COVID-19 among Iraqi people: a web-based cross-sectional study. Journal of Ideas in Health 2020; 3(Special2):258-65. https://doi.org/10.47108/jidhealth.Vol3.IssSpecial 2.59.

78. Rochman ND, Wolf YI, Faure G, Mutz P, Zhang F, Koonin EV. Ongoing global and regional adaptive evolution of SARS-CoV-2. Proc Natl Acad Sci U S A. 2021;118(29):e2104241118. doi:10.1073/pnas.2104241118.

79. Rein T. Harnessing autophagy to fight SARS-CoV-2: An update in view of recent drug development efforts. J Cell Biochem 2021; 1-6. DOI: 10.1002/jcb.30166.

80. Yu S, Jia J, Zheng J, Zhou Y, Jia D, Wang J. Recent progress of Ferroptosis in Lung Diseases. Front. Cell. Dev.Biol. 2021; 9: 789517. doi: 10.3389/fcell.2021.789517. 